GOSPODARKA SUROWCAMI MINERALNYMI - MINERAL RESOURCES MANAGEMENT

2015

Volume 31

Issue 4

Pages $139-150$

DOI 10.1515/gospo-2015-0042

\title{
Fly ash from energy production - a waste, byproduct and raw material
}

\section{Introduction}

Hard coal and lignite are used as primary fuels in the Polish commercial power industry. The process of energy production is associated with the generation of various types of waste. They are classified into 10 groups according to the Regulation of the Minister of the Environment of 9 December 2014 on waste catalogue (Journal of Laws from 2014 item 1923).

The ashes - resulting from hard coal and lignite combustion (10 0102$)$, biomass cobustion (fly ash from peat and chemically untreated wood - 100103 ), co-firing of biomass (10 0117 - fly ash from co-firing other than mentioned in 1001 16), fluidized bed combustion (10 0182 - mixtures of fly ash and solid waste from calcium-based flue gas desulphurization (dry and semi-dry methods of flue gas desulphurization and fluidized bed combustion) have a significant share in power generation waste.

The use of fly ash in Poland has a long tradition, and the most important directions of use include: production of building materials, road construction and mining.

Currently, due to the widespread use of waste from power generation process in the industry, power plants and Combined Heat and Power (CHP) plants are applying for classification of fly ash waste as by-products.

* D.Sc. Eng., AGH University of Science and Technology, Krakow, Poland: e-mail: aub@agh.edu.pl

** Professor, AGH University of Science and Technology, Krakow, Poland.

*** Professor, The Mineral and Energy Economy Research Institute of the Polish Academy of Sciences, Krakow, Poland. 
The concept of by-product was introduced and defined in Article 10 of the Act of 14 December 2012 on waste (Journal of Laws of 2013, item 21, as amended). By definition, an object or substance resulting from a production process, the primary aim of which is not the production of that item, can be regarded as a by-product (not waste), if all the following conditions are met:

1. Further use of an object or substance is certain.

2. An object or substance can be used directly without any further processing other than normal industrial practice.

3. A given object or substance is produced as an integral part of the production process.

4. A given object or substance fulfills all important requirements - including legal requirements - regarding product structure, environmental protection as well as human life and health for a particular use of the aforementioned substances or objects, while such use shall not lead to overall negative impacts on the environment, life and health.

However, in order to apply for the reclassification of a given waste into a by-product, the above requirements must be met. First and foremost, the potential market for the waste-product must be guaranteed.

The current directions of use of fly ash in Poland - as a raw material, by-product or power generation waste - were presented in this paper.

\section{Fly ash resulting from coal combustion}

The fly ash from coal combustion is the most important type of ashes generated in the energy sector (Table 1 and 2).

The ashes from coal combustion are characterized by small fluctuations in the chemical composition while the content of $\mathrm{SiO}_{2}$ and $\mathrm{Al}_{2} \mathrm{O}_{3}$ is usually between $46-50 \%$ and $22-25 \%$, respectively (Kurdowski 2010).

Table 1. The economic use of fly ash from hard coal combustion in the years 2008-2012, thousand tons (10 0102$)$ (Emitor 2009-2013)

Tabela 1. Wykorzystanie gospodarcze popiołów lotnych ze spalania węgla kamiennego w latach 2008-2012 (10 0102 ), tys. ton (Emitor 2009-2013)

\begin{tabular}{|c|c|r|r|r|r|c|}
\hline \multirow{2}{*}{ The year } & \multirow{2}{*}{$\begin{array}{c}\text { The amount } \\
\text { captured }\end{array}$} & \multicolumn{6}{|c|}{$\begin{array}{c}\text { Uuilding } \\
\text { materials }\end{array}$} & Cement & $\begin{array}{c}\text { Road } \\
\text { construction }\end{array}$ & Mining & Others \\
\cline { 3 - 7 } & 3152.1 & 910.2 & 505.9 & 67.0 & 719.8 & 926.0 \\
\hline 2008 & 3344.7 & 1363.7 & 957.2 & 96.6 & 493.6 & 433.9 \\
\hline 2009 & 3583.9 & 1146.9 & 818.8 & 81.2 & 728.0 & 456.6 \\
\hline 2010 & 3798.7 & 1284.6 & 1069.3 & 295.0 & 757.2 & 459.8 \\
\hline 2011 & 3950.6 & 1560.1 & 967.9 & 191.8 & 698.6 & 430.9 \\
\hline
\end{tabular}


Their main, traditional directions of use include the production of building materials, road construction and mining (Table 1 ).

The analysis of data from the years 2008-2012 (Table 1) shows that the vast majority of fly ash is primarily used - with a significant upward trend - in building materials. Cement (a building material itself) production is treated as a separate group of customers. However, the reason for this is the significant share of cement.

A different situation takes place in the case of use of ash from lignite combustion.

According to the data (Table 2) from the Energy Market Agency (Emitor 2009-2014), these ashes are primarily used - with a significant upward trend - in building materials.

The studies have shown the possibility of its use for the production of concrete and cement (Giergiczny 2013), which may expand the amount of fly ash used in the above mentioned technologies in the future.

Table 2. The economic use of fly ash from lignite combustion (10 0102$)$ in the years 2008-2012, thousand tons (Emitor 2009-2013)

Tabela 2. Wykorzystanie gospodarcze popiołów lotnych ze spalania węgla brunatnego w latach 2008-2012 (10 0102 ), tys. ton (Emitor 2009-2013)

\begin{tabular}{|c|c|c|c|c|c|c|}
\hline \multirow{2}{*}{ The year } & \multirow{2}{*}{$\begin{array}{l}\text { The amount } \\
\text { captured }\end{array}$} & \multicolumn{5}{|c|}{ Utilization type } \\
\hline & & $\begin{array}{l}\text { Building } \\
\text { materials }\end{array}$ & Cement & $\begin{array}{c}\text { Road } \\
\text { construction }\end{array}$ & Mining & Others \\
\hline 2008 & 330.4 & - & - & 25.0 & - & - \\
\hline 2009 & 487.8 & 89.0 & - & - & - & 44.4 \\
\hline 2010 & 539.9 & 110.0 & - & - & - & 196.9 \\
\hline 2011 & 821.7 & 190.3 & - & - & - & 291.2 \\
\hline 2012 & $1,067.0$ & 341.0 & - & - & - & 47.5 \\
\hline
\end{tabular}

The total amount of fly ash from coal combustion and procedures - taking both hard coal and lignite combustion into account (Table 3) - are based on the data from the Central Statistical Office of Poland (Environment 2009-2014).

The utilization methods of fly ash - according to the hierarchy required by the Act on Waste - is primarily the recovery, which decreased in 2012 and 2013 when compared to the year 2011, when it reached $92.5 \%$. The amount of ashes subjected to the disposal process increased as compared to 2011. What is more, the storage of fly ash, which was not implemented in the years 2008-2009, was launched. In the years 2012-2013, the amount of landfilled waste increased.

The production of building materials, including cement production, has the greatest potential for the use of fly ash (Table 1). 
Table 3. The utilization methods of fly ash from hard coal and lignite combustion in the years 2008-2013 (Environment 2014)

Tabela 3. Sposoby postępowania z popiołami lotnymi ze spalania węgla w latach 2008-2013 (Environment 2014)

\begin{tabular}{|c|c|c|c|c|c|c|}
\hline \multirow{3}{*}{$\begin{array}{l}\text { The } \\
\text { year }\end{array}$} & \multicolumn{5}{|c|}{ Waste generated during the year } & \multirow{3}{*}{$\begin{array}{c}\text { Waste } \\
\text { landfilled, as } \\
\text { of the end of } \\
\text { the year } \\
\text { [mln tonnes] }\end{array}$} \\
\hline & \multirow{2}{*}{$\begin{array}{c}\text { grand total } \\
{[\mathrm{mln} \text { tonnes }]}\end{array}$} & recovered & total & $\begin{array}{l}\text { of which } \\
\text { landfilled }\end{array}$ & \multirow{2}{*}{$\begin{array}{l}\text { landfilled } \\
\text { temporarily }\end{array}$} & \\
\hline & & \multicolumn{3}{|c|}{$[\%$ of waste generated] } & & \\
\hline 2008 & 4.2 & 90.0 & 8.0 & 0.0 & 2.0 & 18.7 \\
\hline 2009 & 3.7 & 89.5 & 10.0 & 0.0 & 0.5 & 18.7 \\
\hline 2010 & 4.0 & 89.3 & 6.1 & 0.2 & 4.6 & 18.5 \\
\hline 2011 & 4.5 & 92.5 & 4.6 & 0.1 & 0.3 & 19.0 \\
\hline 2012 & 4.6 & 84.4 & 14.7 & 0.1 & 0.9 & 27.2 \\
\hline 2013 & 4.5 & 87.0 & 10.6 & 0.1 & 2.2 & 27.2 \\
\hline
\end{tabular}

The use of fly ash in the production of building materials has been implemented for a long time, which is reflected by the developed standards, which are constantly updated for example with the possibility of using fly ash from co-incineration.

According to the PN-EN-197-1: 2012 standard, fly ash can be used for the following cement types:

- Portland-fly ash cement:

- CEM II/A-V (6-20\% siliceous fly ash),

- CEM II/B-V (21-35\% siliceous fly ash),

- CEM II/A-W (6-20\% calcareous fly ash),

- CEM II/B-W (21-35\% calcareous fly ash).

- Portland-composite cement:

- CEM II/A-M (12-20\% siliceous fly ash or calcareous fly ash),

- CEM II/B-M (21-35\% siliceous fly ash or calcareous fly ash).

- Pozzolanic cement:

- CEM IV/A (11-35\% siliceous fly ash or calcareous fly ash),

- CEM IV/B (36-55\% siliceous fly ash or calcareous fly ash).

- Composite cement:

- CEM V/A (18-30\% calcareous fly ash),

- CEM V/A (31-49\% calcareous fly ash).

The data on the use of fly ash in the cement industry is provided by the Polish Cement Association (Informator 2010-2014) (Table 4).

It is a perspective direction due to the positive influence of fly ash on cement properties and the reduction of $\mathrm{CO}_{2}$ emissions by changing the raw materials (Deja et al. 2010). 
Table 4. The use of fly ash in the cement industry (clinker and cement production), thousand tons (Informator 2010-2014)

Tabela 4. Zużycie popiołów lotnych w przemyśle cementowym (produkcja klinkieru i cementu), tys. ton (Informator 2011-2013)

\begin{tabular}{|c|c|}
\hline Year & Amount of fly ash \\
\hline 2008 & $1,965.4$ \\
\hline 2009 & $1,781.8$ \\
\hline 2010 & $1,850.9$ \\
\hline 2011 & $2,007.25$ \\
\hline 2012 & $1,864.282$ \\
\hline
\end{tabular}

The use of fly ash in concrete production technology is regulated by the PN-EN 450-1, Fly ash for concrete - Part 1: Definitions, specifications and conformity criteria, also permitting a possibility of using fly ash from co-incineration.

Fly ash used in road construction must also meet the requirements of the applicable standards (Rolka and Ślezak 2012; Gawlicki et al. 2009): PN-S-96035:1997 Road. Fly Ash, BS EN 14227-4 Hydraulically bound mixtures. Specifications. Part 4: Fly ash for hydraulically bound mixtures, PN-EN 14227-3 Hydraulically bound mixtures. Requirements. Part 3: Fly ash bound mixtures, PN-EN 14227-5 Hydraulically bound mixtures. Requirements. Part 3: Hydraulic road binder bound granular mixtures, PN-EN 14227-14 Hydraulically bound mixtures. Specification. Part 14: Soil Treated By Fly Ash.

The use of fly ash in mining is regulated by two fundamental standards: PN-G-11010 Mining. Materials for hydraulic backfilling. Requirements and tests and PN-G-11011 Mining. Materials for solidifying backfill and gob grouting, Requirements and testing. This is the traditional and prospective way of use of fly ash in Poland, taking into account the energy and raw material conditions.

\section{Fly ash from the combustion of coal in fluidized bed boilers}

The combustion in fluidized bed boilers is more and more widely used in the power industry in Poland. The amount of fluidized bed boilers has increased since 1998 from 2 up to 21 (including biomass-fired boilers) and 1 hybrid boiler in 2014.

The data on waste (10 01 82) lacks a quantitative distinction between the different types of waste. In addition, there is no accurate data on the amount of fluidized bed ashes.

The amounts of waste (10 0182$)$, including fly ash from fluidized bed boilers, are presented in Tables 5 and 7.

The mining industry, using fly ash in suspension technologies has been the largest recipient of fluidized bed ash from hard coal combustion for many years (Brożyna and Mazurkiewicz 2000, 2003). 
Table 5. The use of waste from hard coal combustion (10 0182$)$, including fluidized bed ashes, thousand tons (Emitor 2009-2013)

Tabela 5. Wykorzystanie odpadów ze spalania węgla kamiennego o kodzie 100182 (w tym popiołów fluidalnych), tys. ton (Emitor 2009-2013)

\begin{tabular}{|c|c|c|c|c|c|c|}
\hline \multirow{2}{*}{ The year } & \multirow{2}{*}{$\begin{array}{c}\text { The amount } \\
\text { captured }\end{array}$} & $\begin{array}{c}\text { Building } \\
\text { materials }\end{array}$ & Cement & $\begin{array}{c}\text { Road } \\
\text { construction }\end{array}$ & Mining & Others \\
\cline { 3 - 7 } & $1,988.3$ & 31.9 & 21.0 & 181.6 & 10.29 & 731.1 \\
\hline 2008 & $1,362.9$ & 26.6 & 15.0 & 178.8 & 814.2 & 475.7 \\
\hline 2010 & $1,463.4$ & 25.0 & 18.1 & 211.3 & 768.4 & 439.6 \\
\hline 2011 & $1,714.9$ & 3.5 & 33.5 & 374.0 & 879.3 & 427.6 \\
\hline 2012 & $1,892.6$ & 27.6 & 21.7 & 270.2 & 792.1 & 777.9 \\
\hline
\end{tabular}

Considerable amounts have also been used in road construction (Table 5).

The PN-EN 14227 standard "Hydraulically bound mixtures" points out the possibility of using fluidized bed ashes, while the PN-EN 13282-2 standard "Hydraulic Road Binders. Normal hardening hydraulic road binders" includes the possibility of using them as a component of hydraulic road binders (Gawlicki and Wons 2011).

Fluidized bed ashes are also used in the production of cement (Tables 5 and 6).

Fluidized bed ashes do not meet the requirements of the standards as raw materials for the production of cement (PN-EN 197-1) and concrete (PN-EN 450-1), as their use requires proper technical approvals (Zapotoczna-Sytek et al. 2013).

Table 6. The use of fluidized bed ashes in the cement industry, tons (Informator 2010-2014)

Tabela 6. Zużycie popiołów fluidalnych w przemyśle cementowym, tony (Informator 2009-2013)

\begin{tabular}{|c|c|}
\hline The years & Amount of fly ash \\
\hline 2008 & 74,000 \\
\hline 2009 & 42,100 \\
\hline 2010 & 23,500 \\
\hline 2011 & 32,774 \\
\hline 2012 & 31,980 \\
\hline
\end{tabular}

The situation is quite different in the case of fluidized ashes from lignite combustion (Table 7). These ashes are classified as waste (10 0182$)$ and their recovery is very limited.

The ashes from fluidized bed combustion of lignite can potentially be used as additives for sealing slurries (Stryczek et al. 2013). 
Table 7. The use of waste from lignite combustion (10 0182$)$, including fluidized bed ashes, thousand tons (Emitor 2009-2013)

Tabela 7. Wykorzystanie odpadów ze spalania węgla brunatnego o kodzie 100182

(w tym popiołów fluidalnych), tys. ton (Emitor 2009 -2013)

\begin{tabular}{|c|c|c|c|c|c|c|}
\hline \multirow[b]{2}{*}{ The year } & \multirow{2}{*}{$\begin{array}{l}\text { The amount } \\
\text { captured }\end{array}$} & \multicolumn{5}{|c|}{ Utilization type } \\
\hline & & $\begin{array}{l}\text { Building } \\
\text { materials }\end{array}$ & Cement & $\begin{array}{c}\text { Road } \\
\text { construction }\end{array}$ & Mining & Others \\
\hline 2008 & $2,167.0$ & - & - & - & - & $2,167.0$ \\
\hline 2009 & $1,914.5$ & - & - & - & - & 31.3 \\
\hline 2010 & $2,165.4$ & - & - & - & - & 11.4 \\
\hline 2011 & $2,331.2$ & - & - & - & - & 16.7 \\
\hline 2012 & $2,252.7$ & - & - & - & - & 23.9 \\
\hline
\end{tabular}

3.8 thousand tons of fly ash generated in biomass-fired plants are classified as waste (10 01 82). According to the data provided by Emitor (2013), they are currently not utilized.

\section{Fly ash from the combustion and co-combustion of biomass}

Fly ashes from the co-combustion of biomass are used in building materials industry (Table 8). The PN-EN 450-1:2012 standard allows for the use of fly ash from co-combustion of solid biofuels, which is the reason why the production of concrete and cement are the most important directions of the use of ashes from biomass combustion.

Table 8. The amount of ashes from the combustion and co-combustion of biomass, thousand tons (Emitor 2090-2013; Uliasz-Bocheńczyk and Mokrzycki 2015)

Tabela 8. Ilość popiołów lotnych ze spalania i współspalania biomasy, tys. ton (Emitor 2010-2014; Uliasz-Bocheńczyk i Mokrzycki 2015)

\begin{tabular}{|c|c|c|c|c|c|c|}
\hline \multirow{2}{*}{ Year } & \multicolumn{4}{|c|}{$\begin{array}{c}\text { Fly ash from peat and } \\
\text { untreated wood }(100103)\end{array}$} & \multicolumn{4}{|c|}{ Fly ash from co-incineration other than those mentioned } \\
\cline { 2 - 7 } & $\begin{array}{c}\text { in } 10116(100117) \\
\text { the amount } \\
\text { captured }\end{array}$ & $\begin{array}{c}\text { industrial } \\
\text { use }- \text { others }\end{array}$ & $\begin{array}{c}\text { the amount } \\
\text { captured }\end{array}$ & $\begin{array}{c}\text { building } \\
\text { materials }\end{array}$ & cement & others \\
\hline 2008 & - & - & 717.8 & 449.0 & 228.0 & 40.7 \\
\hline 2009 & 2.8 & 2.7 & 584.0 & 406.9 & 165.8 & 1.0 \\
\hline 2010 & 3.0 & 0.3 & 557.2 & 423.7 & 132.0 & 1.0 \\
\hline 2011 & 7.9 & 7.1 & 711.9 & 525.3 & 186.4 & 0.2 \\
\hline 2012 & 5.9 & 5.6 & 652.1 & 428.8 & 223.1 & 0.1 \\
\hline
\end{tabular}


Fly ash from the combustion of biomass is also used in the industry. The data provided by Emitor (2009-2013) do not specify the direction of use, but they are not traditional methods of use specified in this study, such as mining, production of building materials or road construction.

The soil and sorbent applications and production of construction materials are potential approach for the fly ash from the combustion of biomass (Vassilev 2013).

\section{Summary and conclusions}

Fly ashes from the energy sector (from coal combustion) are now widely used in the economy. For many years, the fly ash from fluidized bed boilers and conventional boilers has mainly been used in underground mining, production of building materials and road construction. The building materials industry, including the cement industry, also uses ashes from biomass co-combustion. What is more, the fly ash from the combustion of biomass is also used economically.

A much lower recovery rate is achieved for fly ash from lignite combustion; this applies to both fluidized bed boilers and conventional boilers. Further studies on the use of ashes from lignite combustion in building materials production industry - including cement and concrete (Giergiczny 2013) - may increase its recovery in the future.

For this reason, commercial power plants benefit from the possibility to classify fly ash waste as a by-product, enabled by the Act on waste of 14 December 2012, which results in the simplification of the applicable procedures.

However, the basic criterion to reclassify a given waste as a by-product is to guarantee the potential market. If that fails, for example due to changes in the market related to the change of production technology, it may turn out that the market will not be provided and the ashes will once again be classified as waste. In such a case, in addition to the traditional methods of use, such as mining or production of building materials, other possibilities - including the use of fly ash as sorbents for the purification of exhaust gas - should be considered (Ahmaruzzaman 2010; Wang and Wu 2006).

Another possibility might be the use of fly ash and fluidized bed ash, with a particular emphasis on lignite combustion, to bind $\mathrm{CO}_{2}$ in Carbon Capture and Utilization (Uliasz-Bocheńczyk and Mokrzycki 2011).

The research work was supported under the AGH University of Science and Technology Research Program no 11.11.100.482

Artykut opracowano w ramach badań statutowych AGH $\mathrm{nr}$ 11.11.100.482 


\section{REFERENCES}

Act of 14 December 2012 on waste (Journal of Laws of 2013, item 21, as amended).

Ahmaruzzaman, M. 2010. A review on the utilization of fly ash. Progress in Energy and Combustion Science. Elsevier 36, pp. 327-363.

Brożyna, M. and Mazurkiewicz, M. 2000. Możliwości wykorzystania odpadów z palenisk fluidalnych. Materiaty Szkoły Gospodarki Odpadami. Rytro, pp. 33-44 (in Polish).

Brożyna, M. and Mazurkiewicz, M., 2003 - O możliwościach zastosowania odpadów z kotłów fluidalnych jako materiału w podsadzce hydraulicznej - badania laboratoryjne. Miesięcznik WUG Bezpieczeństwo Pracy i Ochrona Środowiska w Górnictwie nr 6 (106) (in Polish).

Deja i in. 2010 - Deja, J., Uliasz-Bocheńczyk, A., Mokrzycki, E. 2010 - $\mathrm{CO}_{2}$ emissions from Polish cement industry. International Journal of Greenhouse Gas Control 4, pp. 583-588.

Emitor 2009, 2010, 2011, 2012, 2013. Emisja Zanieczyszczeń Środowiska w Elektrowniach i Elektrociepłowniach Zawodowych. Agencja Rynku Energii, Warszawa (in Polish).

Environment 2014. Ochrona Środowiska 2014. Główny Urząd Statystyczny, Warszawa 2014.

[Online] www.stat.gov.pl [Access 20.11.2015].

Gawlicki, M. et al. 2009 - Gawlicki, M., Galos, K. and Szlugaj, J. 2013. Mineralne surowce odpadowe z elektrowni, elektrociepłowni i ciepłowni. [W:] Ney, R., red., Surowce mineralne Polski. Kraków: Wyd. IGSMiE PAN, pp. 139-206 (in Polish).

Gawlicki, M. and Wons, W. 2011. Popioły lotne z kotłów fluidalnych jako składniki popiołowo-cementowych spoiw drogowych. Prace Instytutu Ceramiki i Materiałów Budowlanych vol. 4, nr 8, pp. 69-78 (in Polish).

Giergiczny, Z. 2013. Popiół lotny w składzie cementu i betonu. Monografia Politechniki Śląskiej nr 509. Wydawnictwo Politechniki Śląskiej, Gliwice, 189 pp. (in Polish).

Informator 2010-2014, Kraków, Wyd. Stowarzyszenia Producentów Cementu (in Polish).

Kurdowski, W. 2010. Chemia cementu i betonu. Wyd. Polski Cement/Wyd. Naukowe PWN, Kraków/Warszawa, 278 pp. (in Polish).

PN-EN 14227-14 Hydraulically bound mixtures. Specification. Part 14: Soil Treated By Fly Ash.

PN-EN 14227-3 Hydraulically bound mixtures. Requirements. Part 3: Fly ash bound mixtures.

PN-EN 14227-5 Hydraulically bound mixtures. Requirements. Part 3: Hydraulic road binder bound granular mixtures.

PN-EN 450-1 Fly ash for concrete - Part 1: Definitions, specifications and conformity criteria, also permitting a possibility of using fly ash from co-incineration.

PN-EN-197-1: 2012 Cement - Part 1: Composition, specifications and conformity criteria for common cements.

PN-G-11010 Mining. Materials for hydraulic backfilling. Requirements and tests.

PN-G-11011 Mining. Materials for solidifying backfill and gob grouting, Requirements and testing.

PN-S-96035:1997 Road. Fly Ash, BS EN 14227-4 Hydraulically bound mixtures. Specifications. Part 4: Fly ash for hydraulically bound mixtures.

Regulation of the Minister of the Environment of 9 December 2014 on Waste Catalogue (Journal of Laws from 2014 item 1923).

Rolka, G. and Ślęzak, E. 2012. Popioły lotne dla drogownictwa w świetle aktualnych wymagań normowych. Prace Instytutu Ceramiki i Materiałów Budowlanych r. 5, nr 9, pp. 148-155 (in Polish).

Stryczek S. (red.) 2013. Popioły z fluidalnego spalania węgla brunatnego jako dodatek do zaczynów uszczelniających. Wydawnictwa AGH, Kraków, 193 pp. (in Polish).

Uliasz-Bocheńczyk, A. i Mokrzycki, E., 2011. Możliwości zastosowania odpadów energetycznych do mineralnej sekwestracji $\mathrm{CO}_{2}$. Rocznik Ochrona Środowiska 13, pp. 1591-1603 (in Polish).

Uliasz-Bocheńczyk, A. and Mokrzycki, E., 2015. Biomasa jako paliwo w energetyce. Rocznik Ochrona Środowiska 17, p. 900-913 (in Polish).

Wang, S. and Wu, H., 2006. Environmental-benign utilization of fly ash as low-cost adsorbents. Journal of Hazardous Materials B136, pp. 482-501.

Zapotoczna-Sytek G. et al. 2013 - Zapotoczna-Sytek, G., Łaskawiec, K., Gębarowski, P., Małolepszy, J. and Szymczak, J. 2013. Popioły lotne nowej generacji do produkcji autoklawizowanego betonu komórkowego. Wydawnictwo Instytut Śląski Sp. z o.o., Opole, 115 pp. (in Polish). 
POPIOLY Z ENERGETYKI - ODPAD, PRODUKT UBOCZNY, SUROWIEC

Słowa kluczowe

popioły lotne, wykorzystanie gospodarcze, popioły fluidalne, produkty uboczne

\section{Streszczenie}

Energetyka zawodowa w Polsce stosuje jako paliwo węgiel kamienny i brunatny, a w ostatnich latach również biomasę. Procesy produkcji energii elektrycznej i cieplnej w kotłach konwencjonalnych i fluidalnych powodują powstawanie odpadów - przede wszystkim popiołów lotnych. Odpady te są stosowane tradycyjnie w wielu gałęziach przemysłu. Najważniejszymi z nich jest górnictwo, produkcja materiałów budowlanych oraz drogownictwo. Charakterystycznym dla Polski sposobem zagospodarowania popiołów jest ich stosowanie w górnictwie podziemnym w technologii zawiesinowej. Ilość popiołów lotnych 100102 i odpadów 1001 82, w tym popiołów z kotłów fluidalnych, w 2012 roku wyniosła 1490,7 tys. ton. Popioły lotne ze spalania węgla kamiennego w kotłach konwencjonalnych od lat są również wykorzystywane w różnych technologiach produkcji materiałów budowlanych, takich jak: cement, betony, ceramika budowalna oraz kruszywa lekkie. Również popioły ze spalania węgla kamiennego z kotłów fluidalnych znajdują zastosowanie w produkcji cementu i betonów komórkowych. Ze względu na szerokie zastosowanie gospodarcze, zakłady należące do energetyki zawodowej zaczęły przekwalifikowywać popioły lotne ze spalania węgla kamiennego z odpadów na produkt uboczny, po spełnieniu warunków narzuconych przez ustawę o odpadach z dnia 14 grudnia 2012 r. Wykorzystywane są również popioły ze współspalania biomasy.

Problematyczne jest zagospodarowanie popiołów ze spalania węgla brunatnego, zarówno w kotłach konwencjonalnych, jak i fluidalnych, a sumaryczny odzysk popiołów lotnych ze spalania węgla kamiennego i brunatnego w ciągu ostatnich lat obniżył się. $\mathrm{Z}$ tego względu prowadzone są badania nad możliwością ich wykorzystania w tradycyjnych dla popiołów technologiach, takich jak produkcja materiałów budowalnych czy nowych, takich jak zastosowanie jako sorbentów w energetyce czy oczyszczaniu ścieków, a także wiązania $\mathrm{CO}_{2}$ poprzez mineralną sekwestrację w technologii Carbon Capture and Utlilization.

\section{FLY ASH FROM ENERGY PRODUCTION - A WASTE, BYPRODUCT AND RAW MATERIAL}

$$
\text { Keywords }
$$

fly ash, economic use, fluidized bed ash, by-products

$$
\text { Abstract }
$$

Limited use of biomass has been observed in recent years. The processes of electricity and heat production in conventional boilers and fluidized bed boilers generate waste - mainly fly ash. This waste is traditionally used in many industries. The most important are: mining, production of buil- 
ding materials (including cement) and road construction. The use of fly ash in underground mining (suspension technology) is a method of fly ash recovery, which is typical for the Polish industry. The amount of fly ash (10 0102$)$ and waste (10 01 82) including ashes from fluidized bed boilers in the year 2012 amounted to 1,490.7 thousand tons. For many years, fly ashes from hard coal combustion in conventional boilers has also been used in various production technologies of building materials, such as: cement, concrete, building ceramics and lightweight aggregates. The ashes from hard coal combustion in fluidized bed boilers are also used in the production of cement and autoclaved aerated concrete. Due to extensive economic use, commercial power plants started to reclassify fly ash from hard coal combustion, turning waste into a by-product after meeting the requirements of the Act on waste of 14 December 2012. The ashes from the co-combustion of biomass are also used.

The utilization of fly ash from lignite combustion, both from conventional boilers and fluidized bed boilers, is a cause of concern, while the total recovery of fly ash from the combustion of hard coal and lignite has decreased in recent years. For this reason, studies on the use of traditional fly ash technologies such as the production of building materials and new fly ash technologies such as the use as sorbents in power generation and wastewater treatment, as well as on binding $\mathrm{CO}_{2}$ through mineral sequestration in the Carbon Capture and Utilization, are being carried out. 
